\title{
Diversity of D-loop mitochondrial DNA (mtDNA) sequence in Bali and Sumba Ongole cattle breeds
}

\author{
J. Jakaria*, T. Musyaddad, S. Rahayu, M. Muladno and C. Sumantri \\ Department of Animal Production and Technology, Faculty of Animal Science, IPB University, \\ Jl. Agatis, Campus Dramaga, Bogor 16680 - Indonesia \\ *CorrespondingE-mail: jakaria_karman@yahoo.co.id
}

Received August 05, 2019; Accepted October 22, 2019

\begin{abstract}
ABSTRAK
Penelitian ini bertujuan untuk mendapatkan keragaman sekuen lengkap DNA mitokondria D-loop (mtDNA) pada sapi Bali dan Sumba Ongole (SO). Sebanyak 24 sampel darah diperoleh dari sapi Bali (19 ekor) dan sapi SO (5 ekor), diekstraksi dan kemudian dianalisis untuk mendapatkan sekuen mtDNA D-loop. Pensejajaran sekuen mtDNA D-loop dilakukan menggunakan metode clustal $W$. Jarak genetik dihitung menggunakan metode $p$-distance, sedangkan pohon genetik dibangun menggunakan metode Neighbor-Joining (NJ) dengan menggunakan program MEGA 6. Jumlah haplotipe, keragaman haplotipe (Hd) dan keragaman nukleotida (Pi) dianalisis menggunakan program DnaSP versi 6. Diperoleh sekuen mtDNA D-loop pada sapi Bali yaitu panjang 921-1119 bp dan sapi SO 913 bp dan masing-masing memiliki 8 dan 4 haplotipe. Nilai $\mathrm{Hd}$ dan Pi sapi Bali masing-masing 0,625 $\pm 0,139$ dan 0,0266 \pm 0,0145 , sedangkan sapi SO yaitu $0,900 \pm 0,1610$ dan 0,0064 $\pm 0,0015$. Ditemukan 22 bp nukleotida berulang pada sapi Bali dengan jumlah ulangan 3-9 kali dengan panjang 66-198 bp di fragmen mtDNA D-loop. Sekuens berulang tersebut tidak ada pada ternak SO. Jarak genetik dan pohon genetik di daerah hypervariability (HV-1) mtDNA D-loop (166 bp) menghasilkan kluster yang jelas berbeda antara Bos javanicus, Bos indicus, dan Bos taurus.
\end{abstract}

Kata kunci: sapi Bali, D-loop MtDNA, keragaman genetik

\begin{abstract}
This study aimed to investigate the diversity of the complete sequence of D-loop mitochondrial DNA (mtDNA) in Bali and Sumba Ongole (SO) cattle breeds. A total of 24 blood samples were collected from Bali cattle (19 heads) and SO cattle (5 heads), and were extracted and then analyzed to obtain the sequence of D-loop mt DNA. Multiple alignments of the whole sequence of D-loop mtDNA were determined using clustal W. Genetic distance was calculated using a p-distance method, while the genetic tree was constructed using neighbor-joining (NJ) based on MEGA 6. Haplotype number, haplotype diversity $(\mathrm{Hd})$ and nucleotide diversity $(\mathrm{Pi})$ were analyzed using DnaSP version 6. As a result, the sequence of D-loop mtDNA in Bali cattle (921-1119 bp) and SO cattle (913 bp) was reported to have 8 and 4 haplotypes. $\mathrm{Hd}$ and $\mathrm{Pi}$ of Bali cattle reached $0.625 \pm 0.139$ and $0.0266 \pm 0.0145$, respectively, which wwere different from that of SO cattle, namely $0.900 \pm 0.1610$ and $0.0064 \pm 0.0015$, respectively. Specifically, we found 22 bp-repetitive nucleotide in Bali cattle, existing 3-9 times with a length of 66$198 \mathrm{bp}$ present in D-loop mtDNA. This unique feature did not exist in SO cattle. Genetic distance and genetic tree determined according to sequence in hypervariability (HV-1) region of D-loop mtDNA (166
\end{abstract}


bp) resulted in satisfied separation, successfully classifying Bos javanicus, Bos indicus, and Bos taurus cluster.

Keywords: Bali cattle, D-loop MtDNA, genetic diversity

\section{INTRODUCTION}

The most popular and important livestock genetic resources for small holder farmers in Indonesia are Bali cattle (Bos javanicus) and Sumba Ongole (SO) cattle (Bos indicus) (Mohamad et al., 2009). Ongolization program, which is a hybridization of Bali cattle with SO cattle breeds, produces Ongole Grade or Peranakan Ongole (PO) cattle and other breeds in Indonesia such as Madura, Pesisir and Aceh cattle breeds (Martojo, 2012; Hartati et al., 2015). In 1970 , the crossbreeding program was intensively conducted via artificial insemination (AI) (Purwantara et al., 2012) and successfully producing SimPO and LimPO cattle (Trifena et al., 2016). In short, the production of beef cattle in Indonesia is generally based on hybridization between Bali cattle and SO cattle (Nijman et al., 2003; Lenstra et al., 2014; Hartati et al., 2015) and indeed, Bali cattle (Bos javanicus) genetically contributed to Southern Chinese cattle and was found at a very different cluster over other cattle breeds in the world (Gao et al., 2017).

The historical and important role of Bali cattle and SO cattle towards the existence of current breeds in Indonesia evidenced their high adaptability to tropical condition. However, the genetic information of Bali cattle (Bos javanicus) has remained deficient in comparison with that of other breeds such as Bos taurus and Bos inducus (Sharma et al., 2015; Doğan et al., 2017). Regarding studies on genetic diversity and phylogenetic, mitochondrial DNA genome could be the best approach (Rehman et al., 2017) compared to markers from the nuclear genome (Van Marle-Köster and Nel, 2003; Viryanski, 2019). Mitochondrial genome was reported to have a high variability, which is maternally inherited with no recombination (Lenstra et al., 2014), in which the DNA occurred in the form of circular and supercoil molecules with length of $16 \mathrm{~kb}$ in livestock (Rehman et al., 2017); meanwhile, in Bos taurus and Bos indicus, it was found to reach 16.338 and 16.339 nucleotides (Hiendleder et al., 2008). A specific area responsible for controlling genes (37 genes) present in the mitochondrial genome was D-loop comprised of 922 nucleotides (Lee et al., 2012).
For this reason, D-loop mitochondrial is often employed to analyze genetic tree and genetic diversity of cattle breeds (Yang et al., 2014; Sharma et al., 2015; Villegas Castagnasso et al., 2015; Srirattana et al., 2017; Pramod et al., 2018; Xia et al., 2019).

Currently, D-loop mitochondrial based on partial sequencing for investigation of genetic diversity was reported in some cattle breeds such as Aceh cattle (Sari et al., 2016), Bali cattle and Madura cattle (Nijman et al., 2003). Besides, the D-loop mitochondrial analysis was also carried out in Bali cattle, Madura cattle, PO cattle, and Pesisir Sumatra Barat cattle (Sutarno, 2010) as well as SO cattle (Agung and Hermansyah, 2018) using polymerase chain reaction-fragment length polymorphism (PCR-RFLP). Furthermore, D-loop mitochondrial was also sequenced in Bali cattle, Madura cattle, Pesisir cattle, and Aceh cattle (Abdullah et al., 2012) despite using a limited number of samples. Based on our investigation, scientific evidence related to the complete sequence of D-loop mitochondrial in Bali cattle and SO cattle were rather scarce, which make our recent work highly important to conduct. Therefore, this present work aims at discovering the diversity of the D-loop mtDNA sequence in Bali cattle and SO cattle, contributing to future breeding programs for Bali cattle and SO cattle.

\section{MATERIALS AND METHODS}

\section{Animal and Samples}

The D-loop mitochondrial DNA (mtDNA) in this experiment was sourced from 19 individuals of Bali cattle (Breeding Center of Bali cattle in Bali island, Indonesia) and 5 individuals of SO cattle (from smallholder farmer in Nusa Tenggara Timur, Indonesia). Furthermore, we also employed a D-loop sequence from GenBank for cattle breeds including Bos indicus namely Nellore (AY126697.1), Ongole (AY378135.1) and Sahiwal (L27732.1), Bos taurus namely Simmental (AF034442.1), Limousin (AF034446.1) and Angus (AY676858.1).

\section{Mitochondrial Genome Isolation, Amplification and Sequencing}

The mitochondrial genome was isolated 
from blood using the genomic DNA Mini Kit (GenAid protocol Cat. No. GB100). The fragment of D-loop mtDNA in Bali cattle and SO cattle was amplified using forward primer 5'-TAG TGC TAA TAC CAA CGG CC-3' and reverse primer 5'-AGG CAT TTT CAG TGC CTT GC-3' (Hassan et al. 2009) with modification by substituting two nucleotides in forward primer, i.e. 5'-TAG TAC TAA TAC CAA CAG CC-3' according to GenBank Accession No. AY126697.1 in which forward and reverse primer occurred at Cytb and tRNAPhe, which resulted in a sequence length of $1144 \mathrm{bp}$. PCR reaction volume was made up to $25 \mu \mathrm{L}$, consisting of $2 \mu \mathrm{L}$ DNA sample (50-100 ng), $0.3 \mu \mathrm{L}$ of each forward primer and reverse primer $(25 \mathrm{pmol} / \mu \mathrm{L})$, buffer $\left(0.2 \mu \mathrm{L}\right.$ dNTPs, $1 \mu \mathrm{L} \mathrm{MgCl}_{2}$, and $2.5 \mu \mathrm{L} 10 \mathrm{x}$ Buffer), $0.1 \mu \mathrm{L}$ (0.5 U) Taq Polymerase, and 18.9 $\mu \mathrm{L}$ pure water (DW). PCR equipment (Thermoscycler Applied Biosystems) was set as follows: initial denaturation $95^{\circ} \mathrm{C}(5 \mathrm{~min})$, denaturation $95^{\circ} \mathrm{C}$ (30 sec, 35 cycles), annealing $60^{\circ} \mathrm{C}(45 \mathrm{sec})$, extension $72^{\circ} \mathrm{C}(60 \mathrm{sec})$ and final extension $72^{\circ} \mathrm{C}(5 \mathrm{~min})$. PCR product was then electrophoretically analyzed using agarose gel $1.5 \%(0.5 \mathrm{~g}$ dissolved in $33 \mathrm{ml} 0.5 \times \mathrm{XBE})$ and visualized using UV transilluminator. To collect D-loop mitochondrial sequence, PCR fragments were sequenced using ABI PRISM ${ }^{\circledR}$ 3730x1 Genetic Analyzer BigDye ${ }^{\circledR}$ Terminator v3.1 (Applied Biosystems) with 8-capillary system provided by $1^{\text {st }}$ BASE, Selangor Malaysia.

\section{Sequencing Analysis}

The sequence of D-loop mtDNA fragment was analyzed using multiple alignments according to the clustal-W method, while genetic distance was measured using p-distance. Besides, the genetic tree was analyzed using neighbor-joining (NJ) with bootstrap 1000 replication based on Molecular Evolutionary Genetics Analysis (MEGA 6) software (Tamura et al., 2013). Genetic distance and genetic tree for Bali cattle and SO cattle was estimated from hypervariable region (HV-1) with sequence length of D-loop mtDNA reaching up to $166 \mathrm{bp}$, as well as for other cattle breeds based on sequence data from GenBank with accessed number of AY126697.1, Y378135.1, L27732.1, AF034442.1, AF034446.1 and AY676858.1 (http://www.ncbi.nlm.nih.gov). Haplotype variability and diversity of nucleotide in the D-loop mtDNA sequence of Bali cattle and SO cattle were determined by DnaSP version 6 (Rozas et al., 2017).

\section{RESULTS}

\section{Diversity of D-loop mtDNA}

The results showed that D-loop mtDNA in Bali cattle and SO cattle was in accordance with target fragment (Figure 1) with sequence length of 921-1119 bp and $913 \mathrm{bp}$, while variability of haplotype (Hd) and nucleotide (Pi) for Bali cattle and $\mathrm{SO}$ cattle was $0.625 \pm 0.139,0.900 \pm 0.161$ and $0.0266 \pm 0.0145,0.0064 \pm 0.0015$ (Table 1). Even though Bali cattle possessed a greater number of haplotype (8 haplotypes) than SO cattle (4 haplotypes), the variability of haplotype was higher in PO cattle than in Bali cattle. Also, the average number of nucleotide differences $(\mathrm{k})$ and the number of the polymorphic site (s) were higher in Bali cattle than in SO cattle. We also found that the composition of nucleotide in D-

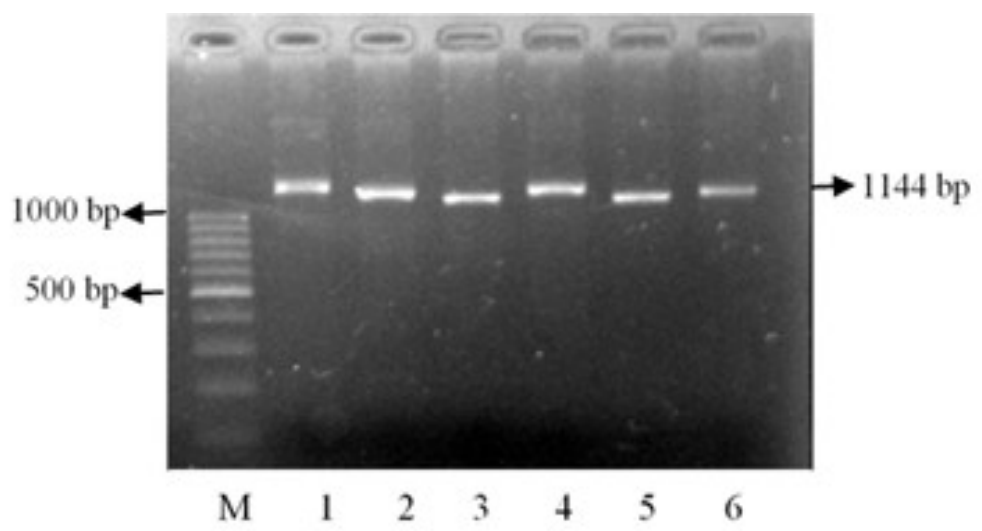

Figure 1. Gel Electrophoresis of PCR Product from a D-loop Mitochondrial Fragment in Bali Cattle SO Cattle. Lane M: marker 100 bp; lane 1-6: samples; bp means base pair 
Table 1. Variability of D-loop MtDNA Sequence in Bali and Sumba Ongole Cattle

\begin{tabular}{ccccccc}
\hline Breed & $\begin{array}{c}\text { Size of } \\
\text { D-loop } \\
(\mathrm{bp})\end{array}$ & $\begin{array}{c}\text { Haplotype } \\
\text { Number }\end{array}$ & $\begin{array}{c}\text { Average Number of } \\
\text { Nucleotide } \\
\text { Differences (k) }\end{array}$ & $\begin{array}{c}\text { Number of } \\
\text { Polymorphic } \\
\text { Site (s) }\end{array}$ & $\begin{array}{c}\text { Haplotype } \\
\text { Diversity (Hd) }\end{array}$ & $\begin{array}{c}\text { Nucleotide } \\
\text { Diversity (Pi) }\end{array}$ \\
\hline Bali & 921 & 8 & 16.54 & 118 & $0.614 \pm 0.130$ & $0.0250 \pm 0.0140$ \\
SO & 913 & 4 & 5.80 & 12 & $0.900 \pm 0.161$ & $0.0064 \pm 0.0015$ \\
\hline
\end{tabular}

Table 2. Frequency of Haplotype of D-loop mtDNA in Bali and Sumba Ongole Cattle

\begin{tabular}{cccccccccc}
\hline \multirow{2}{*}{ Breed } & \multirow{2}{*}{$\begin{array}{c}\text { Haplotype } \\
\text { Number }\end{array}$} & Hap-1 & Hap-2 & Hap-3 & Hap-4 & Hap-5 & Hap-6 & Hap-7 & Hap-8 \\
\hline \multirow{2}{*}{ Bali } & 8 & 0.05 & 0.63 & 0.05 & 0.05 & 0.05 & 0.05 & 0.05 & 0.05 \\
SO & 4 & 0.20 & 0.20 & 0.40 & 0.20 & & & & \\
\hline
\end{tabular}

loop mtDNA between A-T and G-C reached $60.4 \%$ and $39.6 \%$ for Bali cattle (921 bp), and $61.1 \%$ and $38.9 \%$ for SO cattle (913 bp). This suggested that no significant difference in nucleotide composition was found between Bali cattle and SO cattle, but A-T was higher than G-C. Haplotype 2 (Hap-2) in Bali cattle was observed as the highest frequency, while the highest one in SO cattle was haplotype 3 (Hap-3) (Table 2).

Interestingly, repetitive nucleotide was observed in the D-loop mtDNA of Bali cattle, but it did not exist in SO cattle (Figure 2). The presence of $22 \mathrm{bp}$ repetitive nucleotide in Bali cattle is responsible for diversity within the population and dissimilar sequence length (Figure 2). Such repetitive nucleotide was 5'-GTA CAT AAT ATT AAT GTA ATA A-3' with repetition of 3-9 times and found as polymorphic within population; thus, we identified 5 types of repetitive nucleotide according to its replication, and in this case, the highest frequency was attributed to repetitive nucleotide type 1 (Table 3 ). Based on sequence reference of GenBank (AY126697.1), the repetitive nucleotide began with nucleotide with size of 15961-16159 (198 bp), which was specifically found in Bali cattle, while the position of nucleotide with size of 15795-15960 (166 bp) constituted a hypervariability (HV-1) and that with size of $16160-16341,1-366$ (755 bp) was detected as hypervariability (HV-2) (Figure 2).

\section{Genetic Distance and Genetic Tree}

The genetic distance and genetic tree among cattle breeds including Bos taurus and Bos indicus, Bali cattle, and SO cattle were formed in the HV-1 region of D-loop mtDNA with a sequence length of $166 \mathrm{bp}$. The results revealed that the genetic distance between Bos taurus, Bos inducus, and Bos javanicus clusters reached 0.000-0.165 (Figure 3). HV-1 region of D-loop mtDNA (166 bp) was highly effective to classify three clusters of the cattle breed studied (Figure 4). Based on simulation results using the HV-2 region of D-loop mtDNA (755 bp), we found a difference in which the dendrogram showed inconsistency, compared to that from the HV-1 region; therefore, we recommended that clustering of cattle breeds including Bos taurus, Bos inducus, and Bos javanicus should be based on $\mathrm{HV}-1$ region of D-loop mtDNA.

Furthermore, we also found that the 


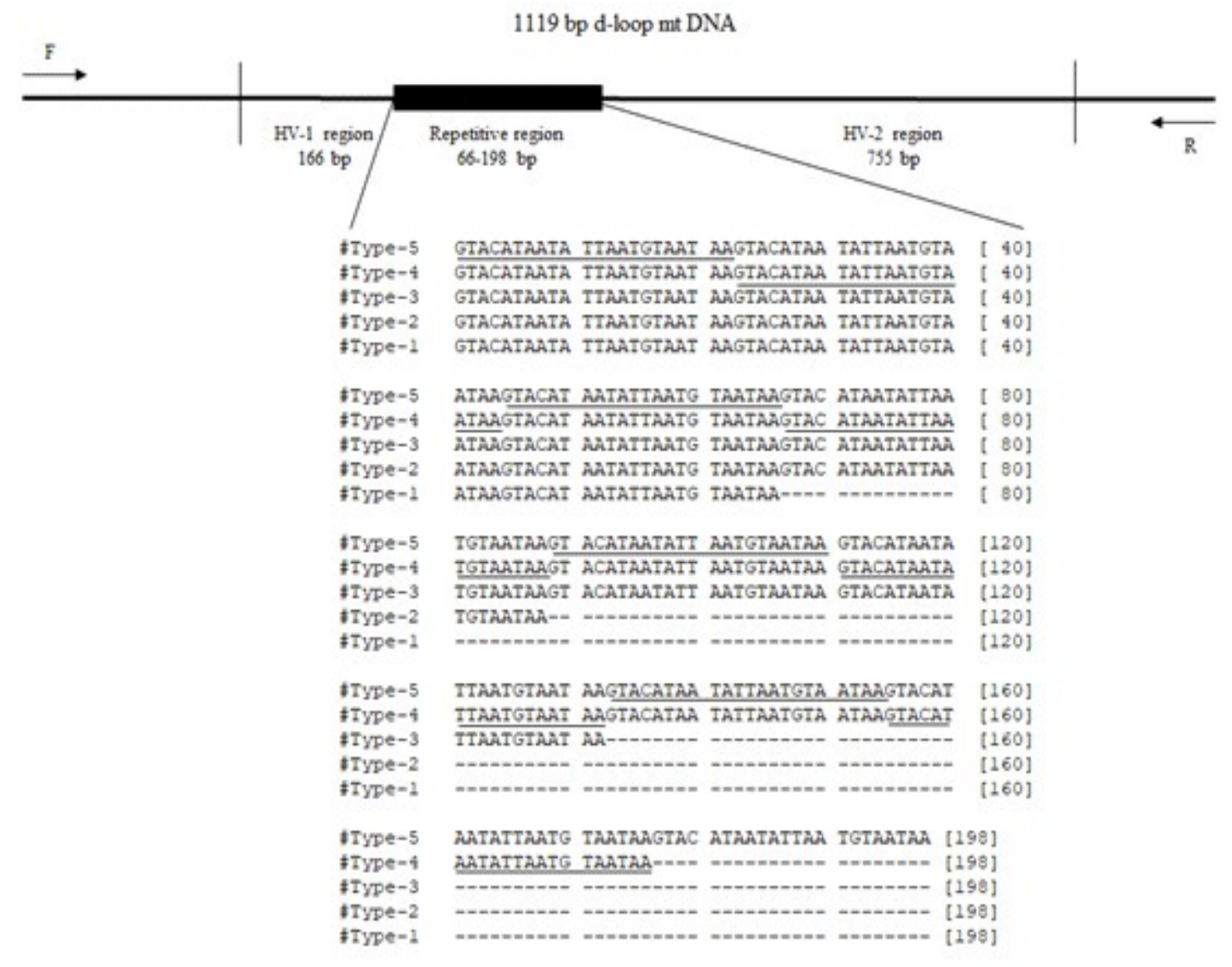

Figure 2. Structure of D-loop mtDNA and Pattern of Repetitive Nucleotide in Bali cattle.

Table 3. The Sequence of Repetitive Nucleotide in D-loop mtDNA of Bali Cattle

\begin{tabular}{ccccc}
\hline No. & Number and Pattern of Repetitive Sequence & Type & $\mathrm{n}$ & Frequency \\
\hline 1 & (GTACATAATATTAATGTAATAA) $_{3}$ & 1 & 9 & 0.474 \\
2 & (GTACATAATATTAATGTAATAA) $_{4}$ & 2 & 2 & 0.105 \\
3 & (GTACATAATATTAATGTAATAA) $_{6}$ & 3 & 4 & 0.211 \\
4 & (GTACATAATATTAATGTAATAA) $_{8}$ & 4 & 2 & 0.105 \\
5 & (GTACATAATATTAATGTAATAA) $_{9}$ & 5 & 2 & 0.105 \\
\hline & Total & & 19 & 1.000 \\
\hline
\end{tabular}

$\mathrm{n}$ is sample number

sequence of the HV-1 region in Bali cattle, SO cattle, and other cattle breeds used to determine genetic distance and genetic tree possessed 28 polymorphic sites (Figure 5). The polymorphic site at nucleotide 162 bp (15795 reference GenBank) was considered as a specific marker for Bos javanicus, Bos indicus and Bos taurus, namely adenine (A), guanine (G) and cytosine 


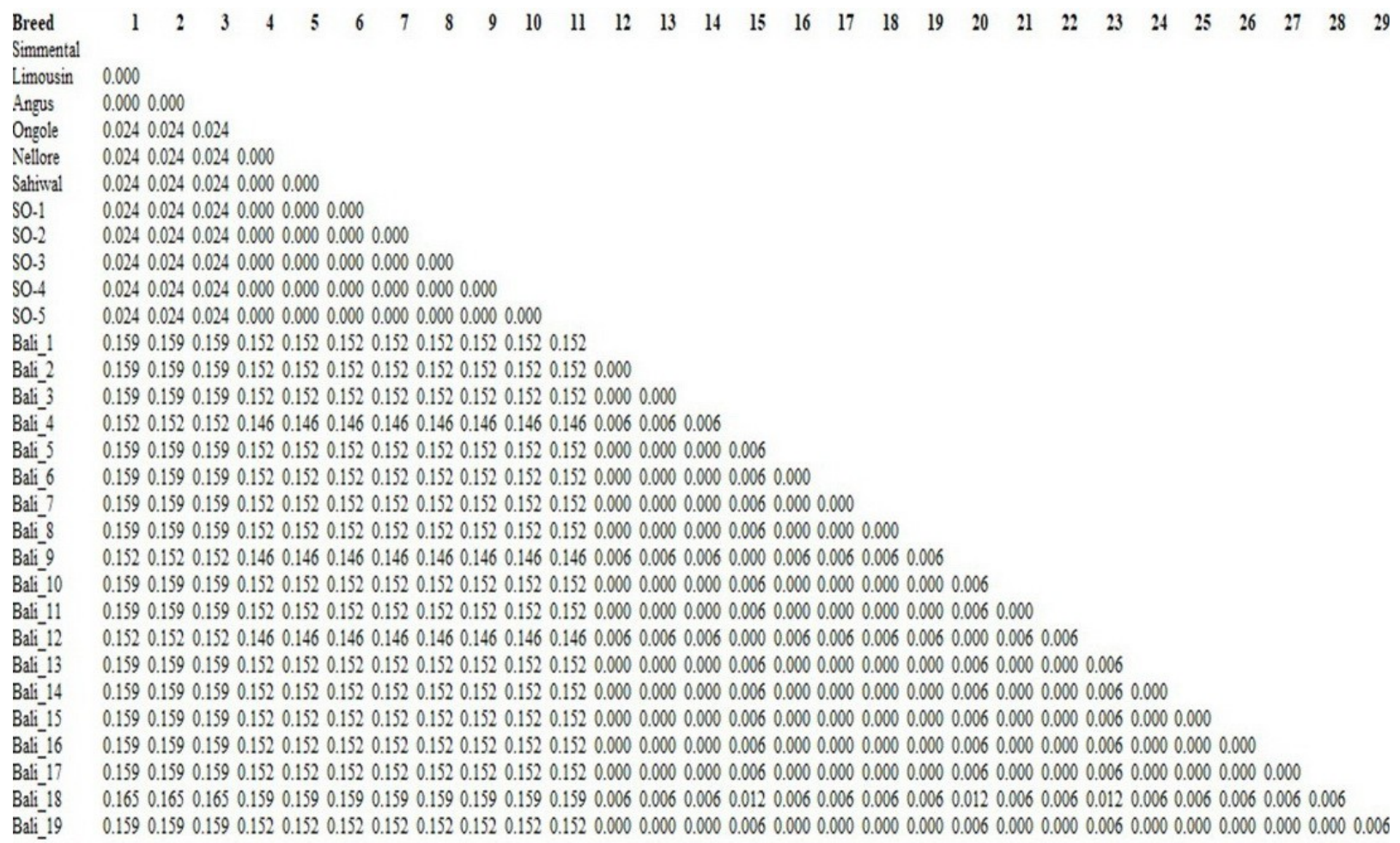

Figure 3. The Genetic Distance of Bali Cattle, SO cattle, and Other Cattle Breeds Based on the HV-1 Region of D-loop mtDNA

(C). Meanwhile, the composition of A-T and G-C in the $\mathrm{HV}-1$ region of D-loop mtDNA was $62.5 \%$ and $37.5 \%$, suggesting no significant difference from the complete nucleotide composition of Dloop mtDNA in Bali cattle (921 bp) and SO cattle (913 bp) (Table 4). The composition of A-T and $\mathrm{G}-\mathrm{C}$ in the repetitive sequence of D-loop mt DNA in Bali cattle was found $86.4 \%$ and $13.6 \%$ (Table 5). Hence, A-T in the repetitive sequence was more abundant than in the HV-1 region at a similar sequence of D-loop $\mathrm{mt}$ DNA. The difference in A-T composition, which is higher in repetitive nucleotide, caused instability of D-loop sequence, while also promoted variability among individuals; thus, this could be then utilized as a genetic marker primarily for Bali cattle due to its high polymorphism.

\section{DISCUSSION}

\section{Variability of D-loop mtDNA in Bali Cattle and Sumba Ongole}

The sequence length of D-loop mt DNA in Bali cattle in this present work varies from 921 to 1119 bp consisting of HV-1 region (166 bp), repetitive nucleotide (66-198 bp) and HV-2 (755 bp). In Bali cattle, variability in length of D-loop mt DNA was due to the presence of $22 \mathrm{bp}$ nucleotide repeatedly present at 3-9 times, while it was also absent in sequence of D-loop mtDNA in SO cattle (913 bp) and other cattle breeds based on gene sequence analysis from GenBank. In the eukaryotic genome, the molecular marker was recognized as microsatellite comprising of repeated di-, tri-, and tetranucleotide (Viryanski, 2019 ) or 1-10 repeated nucleotide, and minisatellite consisting of $10-100$ repeated nucleotide (Van Marle-Köster and Nel, 2003) or 6-100 repeated nucleotide (Vergnaud, 2002). Variability of repetitive nucleotide (22 bp) in Dloop mtDNA as found in Bali cattle can be employed as a DNA specific marker especially for understanding genetic diversity among individuals since they are known as polymorphic.

Bali cattle had higher genetic diversity than SO cattle in terms of allele number, the average number of nucleotide differences, number of polymorphic sites, and nucleotide variability, except for haplotype diversity which was higher in SO cattle than in Bali cattle. The number of 


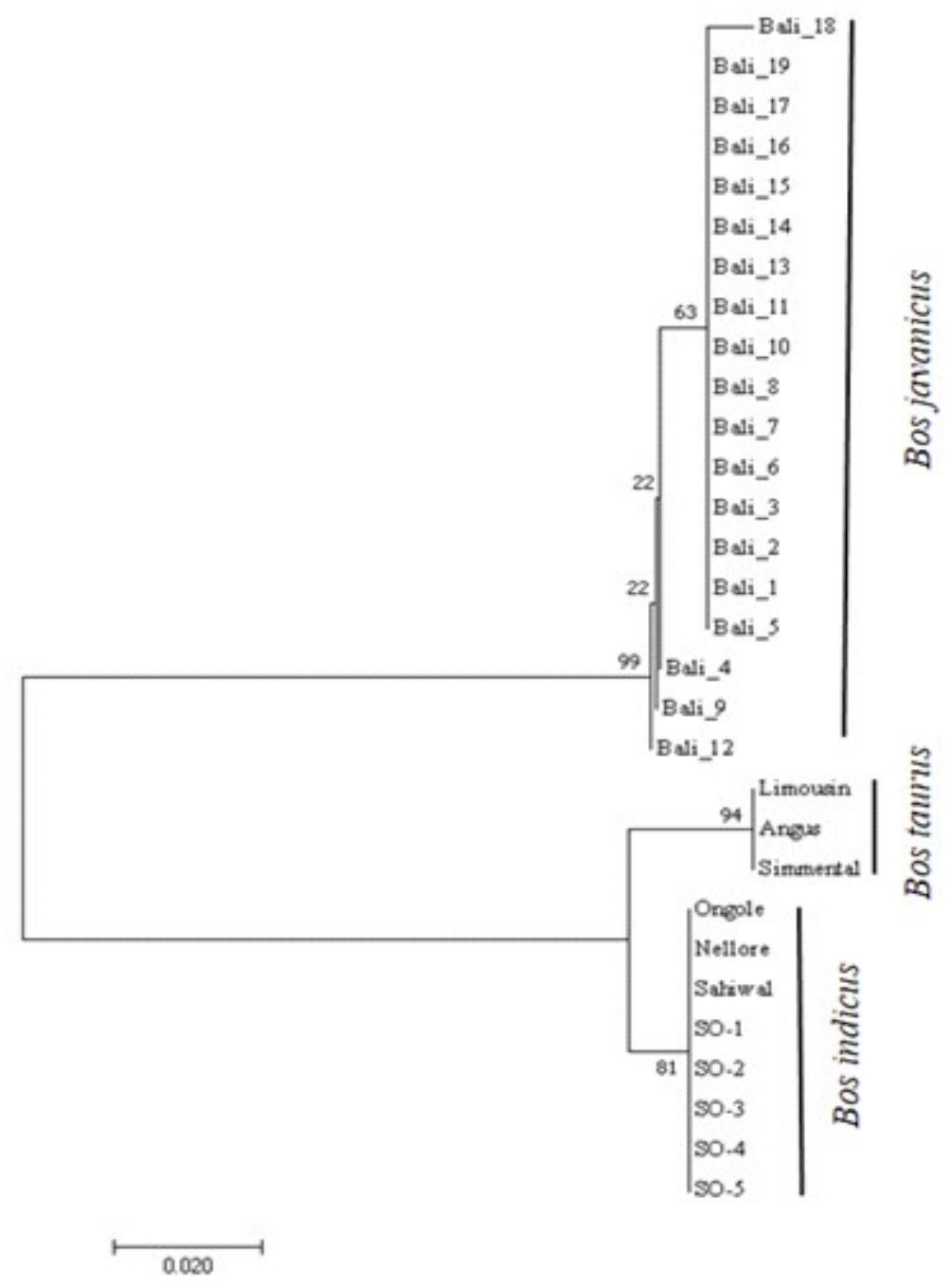

Figure 4. Genetic Tree of Bali Cattle, SO Cattle and Other Cattle Breeds using the Sequence of HV-1 Region of D-loop mtDNA Based on the NJ Method (1000 Bootstrap Replications)

haplotypes is a proper indicator of diversity derived from the maternal line (Ivankovic et al., 2014). Genetic diversity based on haplotype diversity (Hd) and nucleotide diversity (Pi) studied in sequence of D-loop mtDNA has been reported in 27 Podolian cattle breeds reaching 0.837 and 0.010 (Lorenzo et al., 2018), Brahman cattle reaching 0.978 and $0.0143(\mathrm{Qu}$ and $\mathrm{Wu}$, 2006), Brangus-Ibage cattle reaching 0.581 and 0.009 (Henkes et al., 2005) as well as Chinese Wuchuan Black cattle reaching 0.909 and 0.055 (Yang et al., 2014). Our current investigation demonstrated that haplotype diversity and nucleotide diversity in Bali cattle reached 0.625 and 0.026 , while SO cattle reached 0.900 and 0.006 . Although the variability of haplotype and nucleotide seemed to be high in both cattle breeds, haplotype frequency was dominated by haplotype 2 (Hap-2), which might be associated with a reduction of haplotype (8 haplotypes) in Bali cattle (Table 2). The decline in haplotype number and genetic diversity for Bali cattle may relate to an artificial insemination program that has been intensively carried out, which in turn enables to eliminate of a particular haplotype as a specific marker of Bali cattle as a consequence of inbreeding pressure. Besides, the limited use of males for natural mating occurred as a result of inbreeding pressure, thereby alleviating the diversity of Bali cattle and SO cattle.

\section{Genetic distance and genetic tree in Bali cattle and SO cattle}

The results demonstrated cluster separation between Bali cattle (Bos javanicus) and SO cattle (Bos indicus), as well as other cattle breeds 


\begin{tabular}{|c|c|c|c|}
\hline $\begin{array}{l}\text { Position (bp)/ } \\
\text { Breed }\end{array}$ & $\begin{array}{r}223456667 \\
2679053480\end{array}$ & $\begin{array}{r}111111111 \\
8022244455 \\
7324501435\end{array}$ & $\begin{array}{l}11111111] \\
55566667] \\
67802480]\end{array}$ \\
\hline \#Simmental & АTAАTTCСТА & СTCTAAGCAT & TACTCCGG \\
\hline \#Limousin & $\ldots \ldots \ldots$ & $\ldots \ldots \ldots$ & $\ldots \ldots$ \\
\hline \#Angus & $\cdots \cdots \cdots$ & $\cdots \cdots \cdots$ & $\cdots \cdots \cdots$ \\
\hline \#Ongole & $\ldots G \ldots . .$. & $\ldots \ldots$ & . CG.A. \\
\hline \#Ne11ore & $\ldots G \ldots \ldots$ & $\cdots \cdots \cdots$ & $\ldots$ CG.A. \\
\hline \#Sahiwal & $\ldots G \ldots \ldots$ & $\cdots \cdots \cdots$ & ..CG.A. \\
\hline \#SO-1 & $\ldots G \ldots \ldots$ & $\ldots \ldots$ & $\ldots$ CG.A. \\
\hline \#SO-2 & $\ldots G \ldots \ldots$ & $\cdots \cdots \cdots$ & . CG.A. \\
\hline \# SO-3 & $\cdots G \ldots \ldots$ & $\cdots \cdots \cdots$ & . CG.A. \\
\hline \#O-4 & $\cdots G \ldots$ & $\cdots \cdots$ & $\ldots$ CG.A. \\
\hline$\# \mathrm{SO}-5$ & $\ldots G \ldots \ldots$ & $\ldots \ldots$ & $\ldots$ CG.A. \\
\hline \$Bali_1 & GCGGCCTTCG & TСTACССТСС & CСТCAT.A \\
\hline \#Bali_2 & GCGGCCTTCG & TСTACССТСС & CСTCAT.A \\
\hline \#Bali_3 & GCGGCCTTCG & TСTACССТСС & ССТСАТ. А \\
\hline$\$ B a 1 i^{-} 4$ & GCGGCCTT.G & TCTACC-TCC & ССТСАТ. A \\
\hline ¿Bali_5 & GCGGCCTTCG & TCTACССТСC & CСТСАT. A \\
\hline$\$$ Bali_ 6 & GCGGCсTTCG & TСTAСССТСС & CСТСAT.A \\
\hline iBali_ 7 & GCGGCCTTCG & TСTACССТСС & ССТСАT. A \\
\hline \#Bali_8 & GCGGCCTTCG & TCTACССТСC & ССТСАТ.A \\
\hline fBali_9 & GCGGCCTT.G & TCTACССТСС & ССТСАТ. A \\
\hline \#Bali_10 & GCGGCCTTCG & TCTACCСТCC & ССТСАТ. A \\
\hline †Bali_11 & GCGGCCTTCG & TCTACCCTCC & CСТСАT. A \\
\hline iBali__l2 & GCGGCCTT.G & TCTACC-TCC & ССТСAT.A \\
\hline \#Bali__13 & GCGGCCTTCG & TCTACССТСC & ССТСАТ.А \\
\hline \#Bali__ 14 & GCGGCCTTCG & TСТАСССТСС & CСТСAT.A \\
\hline \#ali_15 & GCGGCCTTCG & TCTACССТСС & CСТСАТ. A \\
\hline \#Bali_16 & GCGGCCTTCG & ТСТАСССТСС & ССТСАТ. A \\
\hline iBali_17 & GCGGCCTTCG & TCTACССТСС & ССТСАТ.A \\
\hline \#Bali_18 & GCGGCCTTCG & TCTACССТСС & CСТСAT.A \\
\hline \#Bali_ 19 & GCGGCCTTCG & ТСTАСССТСС & CСТСАT.A \\
\hline
\end{tabular}

Figure 5. Variability of sequence in $\mathrm{HV}-1$ region of D-loop mtDNA.

including Bos taurus, using a sequence of D-loop mtDNA retrieved from GenBank. Previously, the clustering of cattle breeds based on genetic distance and the genetic tree was commonly performed using Bos taurus and Bos inducus (Chung, 2013; Xuan et al., 2010), since reference related to Bali cattle as Bos javanicus cluster has been scarcely available. Genetic diversity of cattle breeds could be researched not only according to partial fragment of D-loop mtDNA (Correia et al., 2017; Sari et al., 2016), complete fragment of dloop mtDNA (Lorenzo et al., 2018), but also whole sequence of mtDNA genome (Pramod et al., 2018). Yet, it is noteworthy that the results of the analysis using entire fragments are expected to collect comprehensive relationships between individuals within species or among species closely related with divergence time (Rehman et al., 2017).

Our experimental results underline that Bali cattle is origin to Indonesia (Martojo, 2012), which is present in different cluster towards other cattle breeds in the world (Lenstra et al., 2014) including SO cattle as Indonesian local cattle imported from Nellore of India by Dutch in hundred years ago (Hartati et al., 2015). Hybridization of Bali cattle (Bos javanicus) with SO cattle (Bos indicus) formed Peranakan Ongole (PO) cattle that accounted for $6-7 \%$ of Bali cattle (Hartati et al., 2015), whereas Bali cattle contributed to Madura cattle (56\%) and Galekan cattle 94\% (Groeneveld et al., 2010). In summary, the existence of Bali cattle exhibited a remarkable contribution to the diversity of cattle breeds in Indonesia, according to current scientific evidence using D-loop mtDNA analysis (Agung and Hermansyah, 2018; Sutarno et al., 2015; Nijman et al., 2003).

\section{CONCLUSION}

The sequence of D-loop mtDNA in Bali cattle ranged from 921 to $1119 \mathrm{bp}$ comprising of HV-1 region (166 bp), 22 bp repeated nucleotide (66-198 bp) and HV-2 region (755 bp), while SO cattle possessed a length of D-loop mtDNA 
Table 4. Composition of Nucleotide in HV-1 Region of D-loop mtDNA

\begin{tabular}{lccccc}
\hline Breed & T(U) & C & A & G & Total \\
\hline Simmental & 22.1 & 25.0 & 43.6 & 9.3 & 172 \\
Limousin & 22.1 & 25.0 & 43.6 & 9.3 & 172 \\
Angus & 22.1 & 25.0 & 43.6 & 9.3 & 172 \\
Ongole & 21.5 & 25.0 & 43.6 & 9.9 & 172 \\
Nellore & 21.5 & 25.0 & 43.6 & 9.9 & 172 \\
Sahiwal & 21.5 & 25.0 & 43.6 & 9.9 & 172 \\
S0-1 & 21.5 & 25.0 & 43.6 & 9.9 & 172 \\
S0-2 & 21.5 & 25.0 & 43.6 & 9.9 & 172 \\
S0-3 & 21.5 & 25.0 & 43.6 & 9.9 & 172 \\
S0-4 & 21.5 & 25.0 & 43.6 & 9.9 & 172 \\
S0-5 & 21.5 & 25.0 & 43.6 & 9.9 & 172 \\
Bali-1 & 21.2 & 28.5 & 39.4 & 10.9 & 165 \\
Bali-2 & 21.2 & 28.5 & 39.4 & 10.9 & 165 \\
Bali-3 & 21.2 & 28.5 & 39.4 & 10.9 & 165 \\
Bali-4 & 22.0 & 27.4 & 39.6 & 11.0 & 164 \\
Bali-5 & 21.2 & 28.5 & 39.4 & 10.9 & 165 \\
Bali-6 & 21.2 & 28.5 & 39.4 & 10.9 & 165 \\
Bali-7 & 21.2 & 28.5 & 39.4 & 10.9 & 165 \\
Bali-8 & 21.2 & 28.5 & 39.4 & 10.9 & 165 \\
Bali-9 & 21.8 & 27.9 & 39.4 & 10.9 & 165 \\
Bali-10 & 21.2 & 28.5 & 39.4 & 10.9 & 165 \\
Bali-11 & 21.2 & 28.5 & 39.4 & 10.9 & 165 \\
Bali-12 & 22.0 & 27.4 & 39.6 & 11.0 & 164 \\
Bali-13 & 21.2 & 28.5 & 39.4 & 10.9 & 165 \\
Bali-14 & 21.2 & 28.5 & 39.4 & 10.9 & 165 \\
Bali-15 & 21.2 & 28.5 & 39.4 & 10.9 & 165 \\
Bali-16 & 21.2 & 28.5 & 39.4 & 10.9 & 165 \\
Bali-17 & 21.2 & 28.5 & 39.4 & 10.9 & 165 \\
Bali-18 & 21.2 & 28.5 & 40.0 & 10.3 & 165 \\
Bali-19 & 21.2 & 28.5 & 39.4 & 10.9 & 165 \\
\hline Average & 21.5 & 27.1 & 41.0 & 10.4 & 167.5 \\
\hline & & & & &
\end{tabular}

reaching $913 \mathrm{bp}$. Both cattle breeds were found to have high variability in haplotype and nucleotide, having 8 and 4 haplotypes, respectively. We also reported 5 types of repetitive nucleotide in Bali cattle, in which they demonstrated a high variability between individuals. Reconstruction of genetic tree based on HV-1 region of D-loop mtDNA (166 bp) could produce clear
Table 5. Composition of Nucleotide in the Repetitive Nucleotide of D-loop mtDNA in Bali Cattle

\begin{tabular}{lccccc}
\hline Breed & $\mathrm{T}(\mathrm{U})$ & $\mathrm{C}$ & $\mathrm{A}$ & $\mathrm{G}$ & Total \\
\hline Bali-1 & 36.4 & 4.5 & 50 & 9.1 & 198 \\
Bali-2 & 36.4 & 4.5 & 50.0 & 9.1 & 66 \\
Bali-3 & 36.4 & 4.5 & 50.0 & 9.1 & 132 \\
Bali-4 & 36.4 & 4.5 & 50.0 & 9.1 & 198 \\
Bali-5 & 36.4 & 4.5 & 50.0 & 9.1 & 66 \\
Bali-6 & 36.4 & 4.5 & 50.0 & 9.1 & 66 \\
Bali-7 & 36.4 & 4.5 & 50.0 & 9.1 & 176 \\
Bali-8 & 36.4 & 4.5 & 50.0 & 9.1 & 66 \\
Bali-9 & 36.4 & 4.5 & 50.0 & 9.1 & 176 \\
Bali-10 & 36.4 & 4.5 & 50.0 & 9.1 & 66 \\
Bali-11 & 36.4 & 4.5 & 50.0 & 9.1 & 132 \\
Bali-12 & 36.4 & 4.5 & 50.0 & 9.1 & 132 \\
Bali-13 & 36.4 & 4.5 & 50.0 & 9.1 & 66 \\
Bali-14 & 36.4 & 4.5 & 50.0 & 9.1 & 66 \\
Bali-15 & 36.4 & 4.5 & 50.0 & 9.1 & 66 \\
Bali-16 & 36.4 & 4.5 & 50.0 & 9.1 & 132 \\
Bali-17 & 36.4 & 4.5 & 50.0 & 9.1 & 88 \\
Bali-18 & 36.4 & 4.5 & 50.0 & 9.1 & 66 \\
Bali-19 & 36.4 & 4.5 & 50.0 & 9.1 & 88 \\
\hline Average & 36.4 & 4.5 & 50.0 & 9.1 & 107.7 \\
\hline & & & & &
\end{tabular}

classification between Bali cattle as Bos javanicus cluster, SO cattle as Bos indicus cluster and other cattle breeds recorded as Bos taurus cluster with 28 polymorphic sites.

\section{ACKNOWLEDGMENTS}

All authors would express thanks to the Ministry of Research, Technology, and Higher Education, Republic of Indonesia, for financial support under Penelitian Dasar Unggulan Perguruan Tinggi (PDUPT) Research Grant number 1757/IT3.11/PN/2018.

\section{REFERENCES}

Abdullah, M.A.N., H. Martojo, R.R. Noor and D.D. Solihin. 2012. Genetic characterization of the aceh cattle using phenotypic, mitochondrial DNA of D-loop region and microsatellite DNA analyses. Reprod. 
Domest. Anim. 47(suppl.1):15-17.

Agung, P. P. and A. Hermansyah. 2018. Identification of a differentiation factor of Indonesian Ongole cattle breeds based on microsatellite markers and mitochondrial DNA. Bulletin of Animal Science. 42(3):184-190.

Chung, H. 2013. Phylogenetic analysis and characterization of mitochondrial DNA for Korean native cattle. Open J. Genet. 03(1):12-23.

Correia, P.B.C., E.E. Baron, J.F.M. da Silva and O.C. Gardyn. 2017. Mitochondrial and Y chromosome genetic diversity in the Portuguese Lidia bovine breed. Rev. Bras. Zootec. 46(2): 99-104.

Doğan, M., M. Nizamlığlu,Y. Özşensoy, E. Kurar, Z. Bulut, V. Altunok, A. Işık and A. Çamlıdağ. 2017. Maternal phylogenetics of some Anatolian cattle breeds. Univers. J. Agric. Res. 5(2):79-84.

Gao, Y., M. Gautier, X. Ding, H. Zhang, Y. Wang, X. Wang, M.D.O. Faruque, J. Li, S. Ye, X. Gou, J. Han, J.A. Lenstra and Y. Zhang. 2017. Species composition and environmental adaptation of indigenous Chinese cattle. Sci. Rep. 7(1):1-14.

Groeneveld, L. F., J.A. Lenstra, H. Eding, M.A. Toro, B. Scherf, D. Pilling, R. Negrini, E.K. Finlay, H. Jianlin, E. Groeneveld and S. Weigend. 2010. Genetic diversity in farm animals - A review. Anim. Genet. 41(Suppl.1):6-31.

Hartati, H., Y.T. Utsunomiya, T.S. Sonstegard, J.F. Garcia, J. Jakaria and M. Muladno. 2015. Evidence of Bos javanicus x Bos indicus hybridization and major QTLs for birth weight in Indonesian Peranakan Ongole cattle. BMC Genet. 16(1):1-9.

Henkes, L. E., W.A. Silva, J.C.F. Moraes and T.A. Weimer. 2005. Mitochondrial control region genetic diversity and maternal ancestry of a Brangus-Ibage cattle populations. Genet. Mol. Biol. 28(1):60-66.

Hiendleder, S., H. Lewalski and A. Janke. 2008. Complete mitochondrial genomes of Bos taurus and Bos indicus provide new insights into intra-species variation, taxonomy and domestication. Cytogenet. Genome Res. 120(1-2):150-156.

Ivankovic, A., S. Paprika, J. Ramljak, P. Dovc and M. Konjacic. 2014. Mitochondrial DNAbased genetic evaluation of autochthonous cattle breeds in Croatia. Czech J. Anim. Sci.
59(11):519-528.

Lee, J., K.T. Lee, S. Ahn, S. Lee, D. Lim, Y.J. Kim, E.S. Cho, K.S. Kim, H. Dadi and T.H. Kim. 2012. Genetic characterization of Northeast Asian cattle based on sequence polymorphisms in the complete mitochondrial genome. Open J. Anim. Sci. 02(4):217-223.

Lenstra, J. A., P. Ajmone-Marsan, A. BejaPereira, R. Bollongino, D.G. Bradley, L. Colli, A. De Gaetano, C.J. Edwards, M. Felius, L. Ferretti, C. Ginja, P. Hristov, J. Kantanen, J.P. Lirón, D.A. Magee, R. Negrini and G.A. Radoslavov. 2014. MetaAnalysis of mitochondrial DNA reveals several population bottlenecks during worldwide migrations of cattle. Diversity 6(1):178-187.

Lorenzo, P.D., H. Lancioni, S. Ceccobelli, L. Colli, I. Cardinali, T. Karsli, M.R. Capodiferro, E. Sahin, L. Ferretti, P.A. Marsan, F.M. Sarti, E. Lasagna, F. Panella and A. Achilli. 2018. Mitochondrial DNA variants of Podolian cattle breeds testify for a dual maternal origin. PLoS One 13(2):112.

Martojo, H. 2012. Indigenous bali cattle is most suitable for sustainable small farming in Indonesia. Reprod. Domest. Anim. 47(Suppl. 1):10-14.

Mohamad, K., M. Olsson, H.T.A. van Tol, S. Mikko, B.H. Vlamings, G. Andersson, H. Rodríguez-Martínez, B. Purwantara, R.W. Paling, B. Colenbrander, and J.A. Lenstra. 2009. On the origin of Indonesian cattle. PLoS One 4(5):1-6.

Nijman, I. J., M. Otsen, E.L.C. Verkaar, C. De Ruijter, E. Hanekamp, J.W. Ochieng, S. Shamshad, J.E.O. Rege, O. Hanotte, M.W. Barwegen, T. Sulawati and J.A. Lenstra. 2003. Hybridization of banteng (Bos javanicus) and zebu (Bos indicus) revealed by mitochondrial DNA, satellite DNA, AFLP and microsatellites. Heredity (Edinb). 90(1):10-16.

Purwantara, B., R.R. Noor, G. Andersson and H. Rodriguez-Martinez. 2012. Banteng and Bali cattle in Indonesia: status and forecasts. Reprod. Domest. Anim. 47(suppl.1):2-6.

Pramod, R. K., D. Velayutham, P.K. Sajesh, P.S. Beena, A. Zachariah, B. Chandramohan, S.S. Sujith, S. Santhosh, S. Iype, P. Ganapathi, B. Dhinoth Kumar, R. Gupta and G. Thomas. 2018. The complete 
mitochondrial genome of Indian cattle (Bos indicus). Mitochondrial DNA Part B Resour. 3(1):207-208.

Qu, K. and G. Wu. 2006. Mitochondrial DNA Dloop Variation and Genetic Background of Brahman Cattle. Zool. 27(6):615-620.

Rehman, S., S. Bano and S. Afzal. 2017. Genetic Diversity in Farm and Wild Animals: A Review. J. Infect. Mol. Biol. 5(1):7-26.

Rozas, J., A. Ferrer-Mata, J.C. SanchezDelBarrio, S. Guirao-Rico, P. Librado, S.E. Ramos-Onsins and A. Sanchez-Gracia. 2017. DnaSP 6: DNA sequence polymorphism analysis of large data sets. Mol. Biol. Evol. 34(12):3299-3302.

Sari, E. M., H. Jianlin, R.R. Noor, C. Sumantri and E.T. Margawati. 2016. Phylogenetic analysis of Aceh cattle breed of Indonesia through mitochondrial D-Loop region. J. Genet. Eng. Biotechnol. 14(1):227-231.

Sharma, R., A. Kishore, M. Mukesh, S. Ahlawat, A. Maitra, A.K. Pandey and M.S. Tantia. 2015. Genetic diversity and relationship of Indian cattle inferred from microsatellite and mitochondrial DNA markers. BMC Genet. 16(1):1-12.

Srirattana, K., K. McCosker, T. Schatz and J.C. St.John. 2017. Cattle phenotypes can disguise their maternal ancestry. BMC Genet. 18:1-11.

Sutarno, S. 2010. Genetic variations among Indonesian native cattle breeds based on polymorphisms analysis in the growth hormone loci and mitochondrial DNA. Biodiversitas, J. Biol. Divers. 11(1):1-4.

Sutarno, A.D. Setyawan and A.J. Lymbery. 2015. Genetic diversity of five indonesian native cattle breeds at microsatellite loci. Asian J. Anim. Sci. 9(2):57-64.

Tamura, K., G. Stecher, D. Peterson, A. Filipski and S. Kumar. 2013. MEGA6: Molecular Evolutionary Genetics Analysis version 6.0. Mol. Biol. Evol. 30(12):2725-2729.

Trifena, T., I.G.S. Budisatria and T. Hartatik. 2016. The phenotypic chages of first fillial and backcross of ongole grade, simpo and limpo cows. Bul. Peternak. 35(1):11-16.

Van Marle-Köster, E. and L.H. Nel. 2003. Genetic markers and their application in livestock breeding in South Africa: A review. South African J. Anim. Sci. 33(1):1-10.

Vergnaud, G and F. Denoeud. 2002. Minisatellites: mutability and genome architecture. Genome Res. 10(7):899-907.

Villegas, C.E.E., A. Rogberg Muñoz, A.J. Prando, A. Baldo and G. Giovambattista. 2015. DLoop mitochondrial genetic analysis in Aberdeen Angus old type from Argentina. J. Basic Appl. Genet. 26(2):29-35.

Viryanski, D. 2019. Microsatellite markers - a tool for molecular characterization of cattle genetic resources. Bul. J. Agric. Sci. 25(1):158-165.

Xia, X., K. Qu, G. Zhang, Y. Jia, Z. Ma, X. Zhao, Y. Huang, H. Chen, B. Huang and C. Lei. 2019. Comprehensive analysis of the mitochondrial DNA diversity in Chinese cattle. Anim. Genet. 50(1):70-73.

Xuan, T. P., S.E. Georgescu, M.A. Manea, A.O. Hermenean and M. Costache. 2010. Phylogenetic relationships of Romanian cattle to other cattle populations determined by using mitochondrial DNA D-loop sequence variation. Rom. Biotechnol. Lett. 15(3):5287-5292.

Yang, S.L., R.Y. Lin, L.X. Xu and L. Cheng. 2014. Analysis of polymorphisms of mitochondrial DNA D-loop and Mc1R gene in Chinese Wuchuan Black cattle. J. Appl. Anim. Res. 42(4): 487-491. 